Caring : Jurnal Keperawatan

Vol.8, No. 1, Maret 2019, pp. $42-47$

ISSN 1978-5755 (Online)

DOI: 10.29238

Journal homepage: http://e-journal.poltekkesjogja.ac.id/index.php/caring/

\title{
Hubungan mekanisme koping dengan perkembangan sosial emosional pada remaja di SMAN 1 Ngaglik Sleman Yogyakarta
}

\section{The relationship between coping mechanism and the adolescences' social \& emotional development in SMAN 1 Ngaglik, Sleman, Yogyakarta}

\author{
Praptiwi $^{1}$, Sulistiyawati ${ }^{1}$, Ngatini $^{1}$ \\ ${ }^{1}$ Program Studi Keperawatan, Universitas Alma Ata Yogyakarta
}

\section{HIGHLIGHTS}

\section{ARTICLE INFO}

\section{Article history}

Keywords:

Coping mechanism

Adolescents' social \& emotional development

Adolescent

\section{A B S T R A C T / A B S T R AK}

Adolescence is a transition period from childhood towards adulthood that needs adjustment to the changes that happened in their life. Teenagers' failure in their social \& emotional development will result in their lack of sensitivity towards the environment and their ability in adapting among their friends. Thus, a tension will occur, and it will result in problem-solving behaviour (coping mechanism). This research attempts to figure out the relationship between the coping mechanism and adolescents' social \& emotional development in SMAN 1 Ngaglik, Sleman, Yogyakarta This research was carried out by using descriptive correlation approach and cross-sectional research design. The research population are class XI students of SMA N 1 Ngaglik, Sleman, Yogyakarta. There are 128 students taken as samples by applying random cluster sampling as the sample collection technique. The data were collected through the social and emotional development questionnaire and coping mechanism questionnaire. Then, the bivariate statistical test utilizes a chi-square test. The majority of the respondents are female with 89 female students $(69.5 \%)$ as respondents. The coping mechanism under the emotionfocused coping category is $69.5 \%$, and the social \& emotional development is adequate, reaching $91.7 \%$. According to the analysis of the correlation test, the p-value is 0.317 . There is no relation between coping mechanism and the adolescents' social \& emotional development in SMAN 1 Ngaglik, Sleman, Yogyakarta

Remaja adalah masa peralihan dari masa kanak-kanak menuju masa dewasa yang memerlukan penyesuaian terhadap perubahan yang terjadi dalam dirinya. Ketidakberhasilan remaja dalam perkembangan sosial emosional akan membuat kurangnya kepekaan terhadap lingkungan,adaptasi dengan teman sehingga timbul ketegangan yang bisa mengakibatkan perilaku pemecahan masalah (mekanisme koping). Mengetahui hubungan antara mekanisme koping dengan kemampuan perkembangan sosial emosional pada remaja di SMA N I Ngaglik Sleman Yogyakarta. Desain penelitian menggunakan pendekatan diskriptif korelasi dengan desain penelitian cross sectional. Populasi siswa kelas XI SMA N I Ngaglik Sleman Yogyakarta dengan tehnik pengambilan sampel cluster random sampling, dengan jumlah sampel 128 siswa. 
Pengumpulan data dengan menggunakan kuisioner
perkembangan sosial emosional dan kuisioner
mekanisme koping. Uji statistik bivariat yang digunakan
adalan uji chi square. Mayoritas responden adalah
perempuan yaitu 89 siswa $(69,5 \%)$. Mekanisme koping
mayoritas dalam kategori emotion focused coping yaitu
$69,5 \%$ dan perkembangan sosial emosional cukup yaitu
$91,7 \%$. Analisis uji korelasi diperoleh p-value 0,317 .
Tidak ada hubungan antara mekanisme koping dengan
perkembangan sosial emosional pada remaja di SMA N
I Ngaglik Sleman Yogyakarta.

Copyright (C) 2019 Caring : Jurnal Keperawatan. All rights reserved

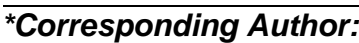

Praptiwi

Program Studi Keperawatan, Universitas Alma Ata Yogyakarta

Jln. Brawijaya No 99, Tamantirto, Kasihan, Bantul, D I Yogyakarta

\section{PENDAHULUAN}

Remaja atau adolesens adalah masa transisi periode perkembangan selama dimana individu mengalami perubahan dari masa kanak-kanak menuju masa dewasa, biasanya antara usia 13 dan 21 tahun. Istilah adolesens biasanya menunjukan maturasi psikologis individu, ketika pubertas menunjukan titik dimana reproduksi mungkin dapat terjadi. Penyesuaian dan adaptasi dibutuhkan untuk menyesuaikan perubahan ini dan usaha untuk membentuk perasaan identitas yang matang.

Jumlah remaja di Indonesia menurut survei demografi kesehatan Indonesia adalah $30 \%$ dari jumlah total penduduk Indonesia yaitu 1,2 juta penduduk. Kondisi remaja di Indonesia saat ini banyak terjadi sex pranikah yang menyebabkan aborsi dengan jumlah 700-800 kasus,HIV AIDS 1253 kasus,penyalahgunaan narkoba sekitar $1,5 \%$ dari total populasi sekitar 3,2 jua jiwa (2). Masalah yang ditemukan berdasarkan penelitian yang dilakukan oleh Puslitbang upaya kesehatan masyarakat pada tahun 2015 didapatkan data remaja merokok 47\%,konsumsi obat terlarang dan minuman alkohol 4,4\%,perilaku seksual 5,3\%, kasus AIDS dan penggunaan zat adiktif $9,8 \%$,kecenderungan gangguan mental emosional 8,7\% (3).

Di Yogyakarta pada tahun 2011 kasus perkelahian antar pelajar mencapai angka 330 kasus yang menewaskan 82 pelajar dan pada tahun 2012 periode Januari sampai Juni mencapai angka 139 yang menewaskan 12 pelajar. Penyalahgunaan narkoba menyebabkan tindakan kriminal yang lain diantaranya pemerkosaan, pembunuhan, pencurian maupun peram-pokan. Hubungan seks pranikah juga menyebabkan penularan penyakit HIV AIDS (4).

Kenakalan remaja biasanya disebabkan karena remaja yang gagal dalam proses perkembangan jiwanya pada masa remaja ataupun kanak-kanak yang disebabkan karena konflik yang tidak terselesaikan seperti trauma pada masa lalu,trauma kondisi lingkungan,trauma kondisi ekonomi yang menyebabkan rendah diri (2). Perkembangan sosial emosional pada remaja adalah kemampuan remaja untuk mencapai identitas dirinya. Kemampuan ini tercapai melalui serangkaian tugas perkembangan yang harus diselesaikan oleh remaja (3).

\section{BAHAN DAN METODOLOGI PENELITIAN}

Jenis penelitian ini adalah diskriptif korelatif dengan mengunakan Desain penelitian cross sectional yang dilakukan di SMA N 1 Ngaglik Sleman Yogyakarta pada bulan desember 2017-januari 2018. Jumlah sampel dalam penelitian ini 128 responden dengan Kriteria : Remaja yang berusia 15-18 tahun, Remaja yang berada di kelas XI 
SMA, Remaja yang bersedia mengisi kuesioner. Uji analisis yang digunakan adalah chi square

\section{HASIL DAN PEMBAHASAN}

Karakteristk Responden

Tabel 1 Distribusi frekuensi responden berdasarkan usia,jenis kelamin, pada remaja siswa kelas XI SMA N I Ngaglik Sleman Yogyakarta pada bulan Januari $2018(\mathrm{n}=128)$

\begin{tabular}{ccc}
\hline Karakter & $(\mathbf{f})$ & $(\%)$ \\
\hline Umur 16-18 tahun & 128 & 100 \\
\hline Jenis Kelamin & 39 & 30,5 \\
Laki-laki & 89 & 69,5 \\
Perempuan & 128 & 100 \\
\hline Total & &
\end{tabular}

Berdasarkan tabel 1 diketahui karakteristik usia anak 16-18 tahun sebanyak $100 \%$, jumlah siswa laki-laki sebanyak $30,5 \%$ dan jumlah siswa perempuan sebanyak $69,5 \%$.

Mekanisme Koping Remaja Siswa Kelas XI SMA N I Ngaglik Sleman Yogyakarta Bulan Januari 2018

Tabel 2 Distribusi Frekuensi Mekanisme Koping Remaja Siswa kelas XI di SMA N I Ngaglik Sleman Yogyakarta Bulan Januari $2018(n=128)$

\begin{tabular}{cccc}
\hline No & Mekanisme Koping & (f) & (\%) \\
\hline 1. & Problem Focused Coping & 39 & 30,5 \\
2. & Emotion Focused Coping & 89 & 69,5 \\
\hline & Jumlah & 128 & 100 \\
\hline
\end{tabular}

Tabel 2 diketahui hasil distribusi frekuensi mekanisme koping adalah siswa yang termasuk dalam kategori problem focused coping yaitu sebanyak 39 siswa $(30,5 \%)$ dan yang termasuk dalam emotion focused coping sebanyak 89 siswa $(69,5 \%)$.

Perkembangan Sosial Emosional Remaja Siswa Kelas XI SMA N I Ngaglik Sleman Yogyakarta Bulan Januari 2018

Tabel 3 Distribusi Frekuensi Perkembangan Sosial Emosional pada Remaja Siswa kelas XI SMA N I Ngaglik SlemanYogyakarta Bulan Januari $2018(n=128)$

\begin{tabular}{cccc}
\hline No & $\begin{array}{c}\text { Perkembangan } \\
\text { Sosial } \\
\text { Emosional }\end{array}$ & (f) & (\%) \\
\hline 1. & Baik & 10 & 7,8 \\
2. & Cukup & 117 & 91,4 \\
3. & Kurang & 1 & 0,8 \\
\hline & Jumlah & 128 & 100 \\
\hline
\end{tabular}

Tabel 4 hasil distribusi frekuensi perkembangan sosial emosional adalah dengan kategori baik 10 siswa (7,8\%), kategori cukup 117 siswa (91,4\%),kategori kurang 1 $(0,8 \%)$ sehingga total keseluruhan adalah 128 siwa (100\%).

Tabulasi Silang Mekanisme Koping dengan Perkembangan Sosial Emosional pada Remaja di SMA N I Ngaglik Sleman Yogyakarta Bulan Januari 2018 
Tabel 4 Tabulasi silang antara Mekanisme Koping dengan Perkembangan Sosial Emosional pada Remaja di SMA N I Ngaglik Sleman.

\begin{tabular}{|c|c|c|c|c|c|c|c|c|c|}
\hline \multirow{3}{*}{$\begin{array}{l}\text { Mekanisme } \\
\text { Koping }\end{array}$} & \multicolumn{8}{|c|}{ Perkembangan Sosial Emosional } & \multirow{3}{*}{$P$-value } \\
\hline & \multicolumn{2}{|c|}{ Baik } & \multicolumn{2}{|c|}{ Cukup } & \multicolumn{2}{|c|}{ Kurang } & \multicolumn{2}{|c|}{ Jumlah } & \\
\hline & f & $\%$ & f & $\%$ & f & $\%$ & f & $\%$ & \\
\hline PFC & 3 & 7,7 & 35 & 89,7 & 1 & 2,6 & 39 & 100 & 0,317 \\
\hline EFC & 7 & 7,9 & 82 & 92,1 & 0 & 0 & 89 & 100 & \\
\hline Total & 10 & 7,8 & 117 & 91,4 & 1 & 0,8 & 128 & 100 & \\
\hline
\end{tabular}

Tabel 4 dapat diketahui sebanyak 3 siswa (7,7\%) memiliki mekanisme koping dalam kategori problem focused coping dengan tingkat perkembangan sosial emosional baik, diketahui sebanyak 35 siswa $(89,7 \%)$ memiliki mekanisme koping dalam dalam kategori problem focused coping dengan tingkat perkembangan sosial emosional cukup, dan diketahui sebanyak 1 siswa $(2,6 \%)$ memiliki mekanisme koping dalam kategori problem focused koping dengan tingkat perkembangan sosial emosional kurang. Dapat diketahui juga sebanyak 7 siswa $(7,9 \%)$ siswa dalam kategori mekanisme koping emotion focused coping dengan tingkat perkembangan sosial emosional baik, dan dapat diketahui sebanyak 82 siswa $(92,1 \%)$ dalam kategori mekanisme koping emotion focused coping memiliki tingkat perkembangan sosial emosional cukup.

Tabel 4.1 dapat diketahui jumlah siswa perempuan lebih banyak yaitu 89 anak. Hasil penelitian menunjukkan remaja di kelas XI SMA N I Ngaglik Sleman cenderung memiliki mekanisme koping kategori EFC karena jumlah siswa perempuan lebih banyak dari laki-laki. Menurut Hawari tahun 2011 perempuan cenderung menggunakan EFC jika menghadapi suatu masalah dan laki laki menggunakan PFC. Perempuan melibatkan usaha-usaha untuk mengatur emosinya dalam rangka menyesuaikan diri dengan dampak yang ditimbulkan oleh suatu kondisi atau situasi yang penuh tekanan. Laki-laki lebih aktif mencari penyelesaian masalah untuk menghadapi suatu kondisi stress secara langsung.

Berdasarkan tabel dapat diketahui siswa SMA N I Ngaglik Sleman Yogyakarta kelas XI sebanyak 89 siwa yang berarti mayoritas siswa memiliki kategori mekanisme koping emotion focused coping. Hal ini sesuai dengan teori yang dikatakan oleh Lazarus bahwa emotion focused coping cenderung dilakukan jika individu tidak mampu mengatur kondisi stress yang dihadapi, yang dilakukan adalah mengatur emosi dalam dirinya.

Hasil penelitian juga menunjukkan 39 siswa memiliki mekanisme koping yang masuk dalam kategori problem focused coping. Siswa mempunyai kategori tersebut karena siswa mampu menganalisa dan memahami masalah dengan lebih baik,mengganti aktivitas untuk mengalihkan pikiran, menyiapkan diri untuk kemungkinan terburuk yang kemungkinan dapat terjadi. Hal tersebut seperti yang diungkapkan oleh Lazzarus dan Folkman problem focused coping adalah strategi kognitif dalam penanganan stress yaitu koping dimana individu secara aktif mencari cara untuk menyelesaikan masalah untuk mengatasi masalah yang menyebabkan stress. Strategi yang digunakan antara lain dengan menentukan masalah, menciptakan alternatif pemecahan, memilih salah satu alternatif tersebut dan mengimplementasikan alternatif yang dipilih tersebut.

Tabel hasil distribusi frekuensi perkembangan sosial emosional adalah kategori cukup sebanyak 117 siswa. Mayoritas siwa memiliki perkembangan sosial emosional cukup. Menurut Santrock perkembangan sosial emosional merupakan kemampuan remaja berperilaku sesuai tuntutan sosial yang berlaku di masyarakat, perkembangan ini dipengaruhi oleh faktor internal yang meliputi kondisi fisik dari seseorang seperti kesehatan, penyakit, susunan syaraf dan lain sebagainya yang berasal dari dalam individu itu sendiri. Selain faktor internal perkembangan ini dipengaruhi oleh faktor eksternal seperti lingkungan keluarga, teman teman sebaya, kebudayaan, pendidikan dan perkembangan remaja. 
Hasil penelitian juga menunjukkan bahwa 10 anak memiliki perkembangan sosial emosional dalam kategori baik. Siswa dengan perkembangan sosial emosional baik mampu mengungkapkan perasaannya dan bisa berdiskusi dengan baik. Hal tersebut sesuai dengan yang dikatakan oleh Gunarsa bahwa tugas perkembangan remaja adalah memperluas hubungan dengan orang lain dan berkomunikasi lebih dewasa dengan orang lain, memperoleh kebebasan emosional dari orang tua, membentuk sistem sistem moral dan falsafah hidup.

Dari hasi penelitian tersebut didapatkan data bahwa hampir semua siswa memiliki kategori cukup dalam perkembangan sosial emosional, yang dapat diasumsikan bahwa siswa-siswa tersebut cukup mampu melaksanakan tugas perkembangan sosial emosional yang saat ini dijalani. Siswa cukup mampu bersosialisasi dengan baik dengan lingkungan dan cukup mampu mengelola emosi dalam berinteraksi dengan orang lain.

Penelitian ini bertujuan untuk mengetahui hubungan antara mekanisme koping dengan perkembangan sosial emosional pada remaja di SMA N I Ngaglik Sleman Yogyakarta. Berdasarka tabel 4.5 memperlihatkan bahwa 35 siswa memiliki mekanisme koping kategori problem focused coping dengan tingkat perkembangan sosial emosional cukup, dan sebanyak 82 siswa dengan mekanisme koping kategori emotion focused coping dengan tingkat perkembangan sosial emosional cukup. Berdasarkan uji statistik chi square dengan menggunakan program komputer SPSS dihasilkan $p$-value 0.317 dengan nilai probabilitas 0,05 . Nilai probabilitas tersebut dibandingkan dengan $p$-value, jika nilai $p$-value $>0,05$ maka Ha ditolak berarti tidak ada hubungan antar dua variabel. Hasil penelitian menunjukkan p 0,317>0.05 hal ini menyatakan tidak ada hubungan antara mekanisme koping dengan perkembangan sosial emosional remaja di SMA N I Ngaglik Sleman Yogyakarta.

Tidak ada perbedaan dalam perkembangan sosial emosional antara siswa yang memiliki kategori problem focused coping maupun emotion focused coping. Sebagian besar siswa memiliki perkembangan sosial emosional yang cukup. Tidak ada hubungan antara mekanisme koping dengan perkembangan sosial emosional pada remaja di SMA N I Ngaglik Sleman Yogyakarta.

Hasil analisis ini menunjukkan tidak adanya perbedaan yang jelas antara siswa dengan kategori mekanisme koping baik problem focused coping maupun emotion focused coping dalam perkembangan sosial emosionalnya. Mekanisme koping yang dialami oleh remaja dipengaruhi berbagai faktor yaitu faktor internal dan faktor eksternal.

\section{KESIMPULAN}

Karakteristik remaja kelas XI SMA N I Ngaglik Sleman Yogyakarta, seluruh siswa berusia 16-18 tahun. Siswa perempuan lebih banyak daripada siswa laki-laki sebanyak $69,5 \%$. Mekanisme koping remaja siswa kelas XI SMA N I Ngaglik Sleman Yogyakarta mekanisme koping sebagian besar siswa masuk kategori emotion focused coping sebesar 69,5\%. Perkembangan sosial emosional remaja siswa kelas XI SMA N I Ngaglik Sleman Yogyakarta menunjukkan sebagian besar siswa memiliki perkembangan sosial emosional cukup sejumlah $91,4 \%$. Tidak ada hubungan antara mekanisme koping dengan perkembangan sosial emosional pada remaja di SMA N I Ngaglik Sleman Yogyakarta dengan nilai $p$-value 0.317 .

\section{DAFTAR PUSTAKA}

1. Nurrahmawati (2012). Mekanisme koping remaja putri yang pernah melakukan hubungan seksual pranikah di Kecamatan Langsar Timur. Skripsi Universitas Sumatra Utara.

2. BKKBN.go.id. (2012) Artikel Fenomena Kenakalan Remaja di Indonesia. Jakarta

3. Liputan6.com Berbagai Perilaku Kenakalan Remaja yang mengkhawatirkan. Jakarta 
4. Liputan6.com (2012) Kenakalan Remaja Sabu Siapa? Jakarta

5. Indarjo S. Kesehatan Jiwa Remaja. Jurnal Kesehatan Masyarakat. (Online) : 2009 (cited 2017 Januari Selasa Available.

6. Susilowati (2014). Stres pada usia remaja di wilayah kerja Puskesmas Klambu Kabupaten Grobokan

7. Ferayanti (2016) Hubungan Mekanisme Koping dengan kemampuan perkembangan psiko social remaja di Madrasah Tsanawiyah Muhammadiyah Yogyakarta Skripsi Universitas Aisyiyah Yogyakarta

8. Fiksi (2016) Hubungan tingkat spiritual dengan tingkat keamanan mekanisme copyng tingkat pertama di FKIP UMY : Yogyakarta

9. Eksani (2015) Hubungan pola anak dengan perkembangan emosional remaja di sekolah menengah negeri 14 Medan

10. Gunarsa \& Singgih (2002) Psikologi Perkembangan. Jakarta : PT. BPK Gunung Mulia

11. Andang,P. 2017. Hubungan Kesejahteraan Spiritual dengan Mekanisme Koping pada Pasien Haemodialisa di Instalasi Dialisis di RSUP Dr Sarjito Yogyakarta: Skripsi Alma Ata Yogyakarta.

12. Dariyo, 2014. Psikologi Perkembangan Remaja, Jakarta : Ghalia Indonesia

13. Sarwono, 2016. Psikologi Remaja, Jakarta : PT. Raja Grafindo Persada

14. Wardani, 2016. Pendidikan Kesehatan Reproduksi di Sekolah, Yogyakarta, Jurnal Bening Vol. VII/No. 1 Mei 2006.

15. Santrock. J.W. 2009 : Adolescene : Perkembangan Remaja. Jakarta : Penerbit Erlangga Alih Bahasa oleh : Shinto B.A dan S. Saragh

16. Hawari, D. 2002. Stres, Cemas, dan Depresi. Jakarta : UI Press Long cit. Putrianti, 2007

17. Clercq, L,D., Smet, B. 2005. Psikologi Kesehatan : Suatu Pendahuluan. Universitas Katholik Sukgijapranata

18. Shiota MN \& Kalaf JW. 2012. Emotion. USA : wodsworth

19. Azzet, Akhmad Muhaimin. 2014. Mengembangkan Kecerdasan Sosial Bagi Anak. Jogjakarta : Kata Hati

20. Utai Ridwan 2015 : Pengaruh teman sebaya di masa perkembangan social remaja. Jakarta : Liputan 6

21. Martani W.2012. Jurnal Psikologi "Metode Stimulasi dan Perkembangan Emosi Anak Usia Dini” Vo. 39, No. 1 Juni 2012 : 112-120.

22. Stuart \& Sudeen. 2007. Buku Saku Keperawatan Jiwa. Edisi 3, Jakarta : ECG

23. Kozier, B.2010. Buku Ajar Fundamental Keperawatan : Konsep, Proses, dan Praktik, Ed 7 Vol 1. Jakarta : EGC

24. Prabowo, E.2014. Konsep dan Aplikasi Asuhan Keperawatan Jiwa. Yogyakarta : Nuha Medika

25. Safaria, T. \& Saputra, N. 2009. Manajemen Emosi : Sebuah Panduan Cerdas Bagaimana Mengelola Emosi Positif dalam Hidup Anda. Jakarta : Bumi Aksara.

26. Mulyanti, M Agung K, 2015. Alma Ata Jurnal Ners dan Kebidanan:Hubungan Mekanisme Koping dengan Tingkat Depresi pada Mahasiswa Tingkat Akhir. Yogyakarta:Alma Ata

27. Hamid, Achir \& Ibrahim Kusman. 2017. Pakar Teori Keperawatan dan Karya Mereka. Singapura : Elservior.

28. Sugiyono. 2007. Statistik Untuk Penelitian. Bandung : Alfabeta.

29. Machfoedz, Ircham. 2008. Metodologi Penelitian (Kuantitatif dan Kualitatif) Yogyakarta : Fitramaya

30. Sugiyono. 2011. Statistik Untuk Penelitian. Bandung : Alfabeta

31. Saryono. 2013. Metodologi Penelitian Kualitatif dalam Bidang Kesehatan. Yogyakarta : Nuha Medika 